\title{
MENGAKOMODASI EFEK METODE DALAM PENGUJIAN VALIDITAS KONSTRUK MELALUI ANALISIS FAKTOR KONFIRMATORI
}

\author{
Wahyu Widhiarso ${ }^{1 *}$ \\ ${ }^{1}$ Fakultas Psikologi, Universitas Gadjah Mada, Yogyakarta, Indonesia
}

\begin{abstract}
Literatures in the field of psychometrics recommend researchers to employ various of methods on measuring individual attributes. Ideally, each methods are complementary and measures the construct designed to be measured. However, some problems arise when among the methods is unique and unrelated to the construct being measured. The uniqueness of method can lead what is called the method effect. In testing construct validity using confirmatory factor analysis, the emergence of this effect tend to reducing the goodness of fit indices of the model. There are many ways to solve these problem, one of them is controling the method effects and accommodate it to the model. This paper introduces how to accommodate method effect on the confirmatory factor analysis using structural equation modeling. In the application section, author identify the emergence of method effects due to the differences item writing direction (favorable-unfavorable). The analysis showed that method effect emerge from different writing direction.
\end{abstract}

Keywords: Method Construct, Method Effect, Positive-negatively worded items.

\begin{abstract}
ABSTRAK
Literatur dalam bidang psikometri merekomendasikan kepada peneliti untuk menggunakan metode yang bervariasi dalam mengukur atribut individu. Idealnya antara satu metode dengan metode yang lain bersifat komplementer dan tetap mengukur konstruk yang didesain untuk diukur. Permasalahan muncul ketika antar metode memiliki keunikan yang tidak terkait dengan konstruk yang diukur. Keunikan ini memunculkan apa yang dinamakan dengan efek metode. Dalam pengujian validitas konstruk melalui analisis faktor konfirmatori, munculnya efek metode menurunkan nilai kecocokan model. Ada banyak cara untuk mengatasi permasalahan ini, salah satunya adalah dengan mengendalikan efek metode dengan cara mengakomodasinya dalam pemodelan. Tulisan ini memperkenalkan beberapa model yang dapat mengakomodasi efek. Pada bagian contoh aplikasi, penulis mengidentifikasi munculnya efek metode akibat perbedaan arah penulisan butir. Hasil analisis menunjukkan bahwa efek metode muncul dari arah penulisan butir yang berbeda.
\end{abstract}

Kata kunci: Konstruk Metode, Efek Metode, Butir Positif-Negatif 


\section{PENDAHULUAN}

Dalam pengujian validitas konstruk melalui analisis faktor konfirmatori (CFA) melalui pemodelan persamaan struktural (SEM), indeks kecocokan model yang tinggi akan didapatkan ketika model yang diuji dapat menjelaskan data dengan baik. Hal ini terlihat dari nilai residu (misalnya indeks RMSEA) yang didapatkan sangat kecil yang menunjukkan semua keragaman di dalam data dapat dijelaskan oleh model (Raykov \& Marcoulides, 2006). Sebaliknya, ketika model tidak menjelaskan keragaman data dengan baik maka kecocokan model dengan data cenderung rendah. Dalam konteks pengujian validitas konstruk alat ukur melalui CFA, kecocokan model didapatkan ketika indikator-indikator yang diuji menjelaskan keragaman data berdasarkan konstruk ukur sepenuhnya. Di dalam teori psikometri, keragaman-keragaman di dalam data yang diakibatkan oleh selain konstruk yang diukur dipertimbangkan sebagai sesatan atau eror pengukuran. Semakin besar porsi eror pengukuran yang dihasilkan oleh sebuah pengukuran maka semakin kecil nilai kecocokan model dengan data (Kline, 2011).

Eror pengukuran dapat bersifat non sistematik dan sistematik. Eror pengukuran yang bersifat non sistematik bersifat random sehingga relatif sulit dimodelkan (modeled). Di sisi lain, eror pengukuran yang bersifat sistematik tidak bersifat random dan memiliki pola yang dapat diidentifikasi. Dalam perspektif SEM, adanya eror sistematik ini menunjukkan bahwa ada keragaman atau pola yang tidak dapat dijangkau oleh model. Saat ini berbagai macam model-model untuk mengakomodasi pengujian validitas konstruk mulai diperkenalkan (Dallal, 2005; Morizot, Ainsworth, \& Reise, 2007). Model-model yang terbaru juga sudah diaplikasikan dalam penelitian praktis (Cummins, Woerner, Tomyn, \& Gibson-Prosser, 2012; Gu, Wen, \& Fan, 2015; Maitland \& Presser, 2016).

Keragaman yang tidak terjelaskan ini dapat diakibatkan oleh dua penyebab:

1. Konstruk Ukur (trait). Munculnya keragaman disebabkan oleh konstruk ukur lain di luar konstruk yang sengaja diukur. Misalnya pengukuran depresi secara tidak langsung juga mengukur kecemasan (McLaughlin, Khandker, Kruzikas, \& Tummala, 2006). Jika dualisme pengukuran ini diaplikasikan dalam pemodelan maka dihasilkan sebuah model yang memuat dua konstruk laten sebanyak dua buah.

2. Konstruk Metode. Munculnya keragaman yang tidak termodelkan dapat juga disebabkan oleh apa yang dinamakan dengan konstruk metode (method construct) 
(Podsakoff, MacKenzie, \& Podsakoff,

2011). Konstruk metode menunjukkan

bahwa butir-butir yang memiliki kesamaan

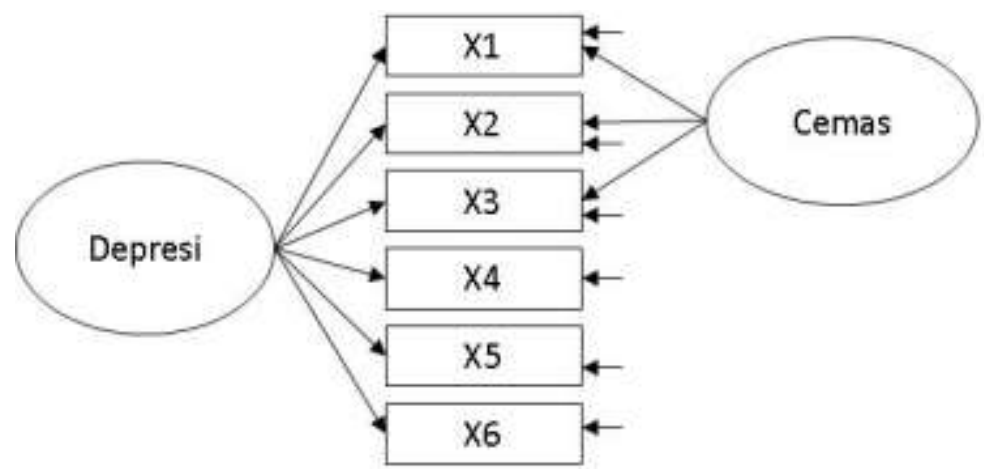

(a) Model Bifaktor dalam menjelaskan sebuah konstruk laten dan kesamaan tersebut berdasarkan metode pengukuran (Andrews, 1984)

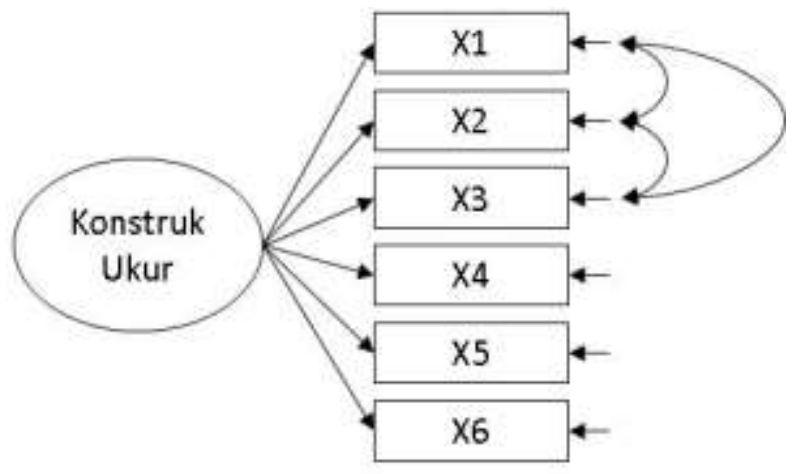

(b) Model Korelasi antar Eror

Gambar 1. Model Bifaktor dan Model Korelasi antar Eror

Gambar 1 menggambarkan bagaimana memodelkan keragaman di luar konstruk ukur utama (depresi). Pada Gambar 1(a) tiga butir (X1, X2, X3) selain mengukur depresi terbukti juga mengukur kecemasan. Situasi yang sama juga dapat dimodelkan pada Gambar 1(b) dengan memberikan adanya korelasi antar eror pengukuran dari ketiga butir. Kedua gambar yang disajikan pada Gambar 1 secara umum adalah sama. Bedanya, pada Gambar 1(a), keunikan ketiga butir tersebut dieksplisitkan dalam satu konstruk laten, sedangkan pada Gambar 1(b) kesamaan tersebut tidak dieksplisitkan.

Tentunya, konstruk yang dieksplisitkan tersebut tidak memiliki makna, karena program analisis hanya mengidentifikasi kesamaan saja.
Oleh karena itu peneliti mengidentifikasi kesamaan tersebut dan memberi nama berdasarkan kesamaan tersebut. Setelah kesamaan diidentifikasi Gambar 1(a) ketiga butir memiliki kesamaan konten yang terkait dengan kecemasan. Ketika sebuah alat ukur yang bersifat dualistik akan tetapi sifat tersebut tidak dilibatkan dalam model yang diuji, maka indeks kecocokan model yang dihasilkan cenderung kecil. Kesimpulan yang dapat ditarik adalah keunikan yang tidak termodelkan dapat diakibatkan oleh munculnya dualisme pengukuran atau efek metode (Castro-Schilo, Grimm, \& Widaman, 2016). Ada dua cara dalam mengakomodasi keunikan butir yang tidak termodelkan yaitu dengan mengeksplisitkannya sebagai konstruk laten 
atau mengakomodasinya dalam bentuk korelasi antar eror (Abad, Sorrel, Garcia, \& Aluja, 2016).

\section{Pengertian Metode}

Apakah keunikan yang tidak muncul dalam pemodelan merupakan konstruk ukur atau metode kadang sulit untuk dibedakan. Sebagai contoh tiga butir (X1, X2, X3) yang memiliki keunikan, sulit untuk dibedakan apakah keunikan tersebut merepresentasikan konstruk ukur baru ataukah karena memiliki metode yang sama. Oleh karena itu penelit perlu untuk memahami definisi metode.

Kata metode dalam konsep pengukuran memiliki arti yang luas. Fiske (1982) mendefinisikan metode dalam lingkup luas yang mencakup beberapa aspek penting dalam proses pengukuran termasuk: konten butir, format respons, petunjuk umum atau administrasi pengukuran serta fitur lain dari alat ukur seperti instruksi kepada responden, karakteristik individu dan tujuan pengukuran. Oleh karena itu analisis yang dilakukan pada tulisan ini dapat diterapkan pada lingkup yang lebih luas. Metode dapat diartikan sebagai cara mengukur, misalnya melalui pelaporan diri dan observasi (Kline, 2011), metode dapat mengacu pada sumber pengukuran (diri sendiri, orang lain) (Urbina, 2004), model skala (Likert, diferensial semantik) juga dapat dilihat sebagai metode berbeda (D. A. Kenny, 1976). Selain itu, metode dapat juga didefinisikan sebagai arah pernyataan dalam skala psikologi (favorable, unfavorable) (Marsh, 1996), administrasi pengukuran (paper, komputer), dan bahkan alat ukur yang berbeda dapat dikatakan juga sebagai metode yang berbeda (Marsh, Asci, \& Thomas, 2002).

Ada juga ahli yang mendefinisikan kata metode secara lebih ketat. Lance et al . (2009) misalnya, membatasi metode sebagai pendekatan alternatif dalam menetapkan angka dalam proses pengukuran. Kata kunci dari definisi ini adalah pendekatan alternatif. Bersifat alternatif dapat juga diartikan bersifat substitutif atau dapat saling menggantikan. Dari definisi ini maka konten butir, observer, struktur dan format alat ukur serta waktu dan situasi pengukuran dapat dikatakan sebagai sebuah metode, karena saling menggantikan (Podsakoff et al., 2011). Sebagai contoh, alat ukur adalah sampel perilaku dari individu yang diukur. Oleh karena menggali sampel perilaku, maka kontenkonten yang berbeda pada butir-butir di dalam alat ukur bersifat substitutif. Berangkat dari pengertian di muka, konten butir dapat dianggap sebagai sebuah metode pengukuran.

Sementara itu, Podsakof dkk. (2011) lebih memilih definisi metode yang lebih luas. Tidak masalah apakah definisi metode itu memuat gaya respon individu, karakteristik 
butir, atau aspek-aspek konteks pengukuran. Sepanjang apa yang dicontohkan tersebut teridentifikasi sebagai faktor metode, maka ketiga hal tersebut berpotensi sebagai sumber kesalahan pengukuran sistematik yang dapat mengancam validitas. Jika faktor metode ini diabaikan mereka dapat mengancam validitas konstruk, mendistorsi struktur dimensi domain psikologis, dan hubungan antar konstruk. Namun demikian, perbedaan antara konstruk ukur (trait) dan metode, tergantung pada bagaimana penyusun alat ukur mendefinisikannya. (Campbell \& Fiske, 1959).

\section{Efek Metode}

Sejauh ini pembaca telah dijelaskan mengenai konsep adanya konstruk baru di luar konstruk yang sengaja diukur. Ketika butir-butir yang merefleksikan konstruk baru tersebut memiliki kesamaan dalam hal metode, maka dinamakan dengan konstruk metode. Peranan konstruk metode ini dalam menjelaskan keragaman data dinamakan dengan efek metode (method effect). Jika efek ini mengganggu pengukuran maka dinamakan dengan bias metode (method bias). Adanya efek metode dapat dilihat sebagai kekuatan maupun kelemahan pengukuran, tergantung pada tujuan peneliti melibatkan beberapa metode di dalam alat ukur. Jika efek metode muncul dari dua metode yang bersifat komplementer, maka munculnya efek metode menunjukkan kekuatan pengukuran. Ketika penggabungan pengukuran dengan menggunakan dua metode berbeda (misalnya observasi dan pelaporan mandiri) memunculkan efek metode, maka hal ini menunjukkan kekuatan pengukuran. Kekuatan tersebut menjelaskan bahwa masing-masing metode mengukur sesuatu yang khas dari konstruk yang ukur. Sebaliknya, jika metode yang dipakai bersifat substitutif (dapat saling menggantikan), maka munculnya efek metode menunjukkan kelemahan pengukuran (Lance et al., 2009; Podsakoff et al., 2011). Idealnya, dua metode yang bersifat substitutif tidak mengukur kekhasan konstruk ukur. Jika kedua metode tersebut memunculkan kekhasan berupa efek metode, maka efek ini dapat ditafsirkan sebagai bias metode.

Munculnya bias metode dalam pengembangan alat ukur dapat disebabkan oleh dua faktor, yaitu faktor responden dan faktor alat ukur (MacKenzie \& Podsakoff, 2012). Dari sisi responden, bias metode muncul ketika tanggapan yang diberikan oleh responden terhadap alat ukur tidak mencerminkan konstruk yang diukur. Hal ini mereka lakukan secara konsisten terhadap butir-butir di dalam alat ukur. Sebagai contoh, penggunaan butir dengan arah ukur yang berbeda, yaitu butir yang berarah positif (favorable) dan negatif (unfavorable) 
dapat dilihat sebagai dua metode pengukuran yang berbeda (Marsh, 1996). Bias metode muncul ke permukaan ketika cara responden dalam menanggapi kedua metode tersebut berbeda. Misalnya responden yang cenderung menyetujui pernyataan positif dan menolak pernyataan negatif. Kedua metode ini bersifat substitutif sehingga diharapkan tanggapan responden pada butir di dalam alat ukur tidak terpengaruh oleh jenis metode yang dipakai. Ketika kecenderungan responden dalam memberikan tanggapannya dipengaruhi oleh metode, maka efek metode muncul sebagai konstruk yang baru.

\section{PEMBAHASAN}

\section{Mengakomodasi Efek Metode dalam Pemodelan}

Adanya berbagai metode pengukuran menginspirasi Campbel dan Fiske (1959) untuk mengembangkan konsep pengujian validitas konstruk melalui pendekatan multitrait multimetode (MTMM). Sebuah alat ukur dikatakan memenuhi validitas konstruk ketika dikorelasikan dengan alat ukur yang mengukur atribut sama (akan tetapi menggunakan metode yang berbeda) menghasilkan korelasi yang tinggi, dibandingkan ketika dikorelasikan dengan alat ukur yang mengukur atribut berbeda. Dari konsep ini terlihat bahwa metode pengukuran diharapkan tidak mempengaruhi perolehan skor individu. Dengan mengesampingkan apakah alat ukur menggunakan metode $\mathrm{A}$ ataukah $\mathrm{B}$, ketika nilai korelasi yang didapatkan adalah tinggi maka skor yang dihasilkan kedua alat ukur dapat dinyatakan valid.

Beberapa ahli telah mengembangkan model CFA yang mengakomodasi efek metode (Geiser, Eid, West, Lischetzke, \& Nussbeck, 2012). Model ini berbeda dengan model CFA konvensional yang biasa dipakai. Ada beberapa modifikasi yang dilakukan pada model konvensional tersebut. Modifikasi tersebut dapat berupa: (a) mengkorelasikan antar eror pengukuran, yang dinamakan dengan varians metode (method variance) dan (b) menambahkan konstruk baru yang dinamakan dengan konstruk metode atau kadang dinamakan dengan faktor metode (method factor) (David A. Kenny \& Kashy, 1992). Gambar 2 menjelaskan perbandingan empat metode CFA untuk pengukuran dua konstruk ukur (trait) yang sama (T1 dan T2) yang diukur dengan menggunakan dua metode (M1 dan M2). Metode 1 berisi butir X1-X4 sedangkan metode 2 berisi X5-X8. Gambar 2(a) menjelaskan model acuan (baseline), yaitu model analisis faktor konfirmatori standar yang tidak melibatkan efek metode dalam model. 


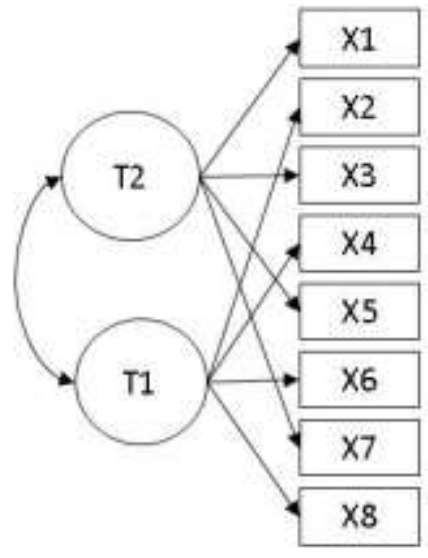

(a) Model CFA Biasa

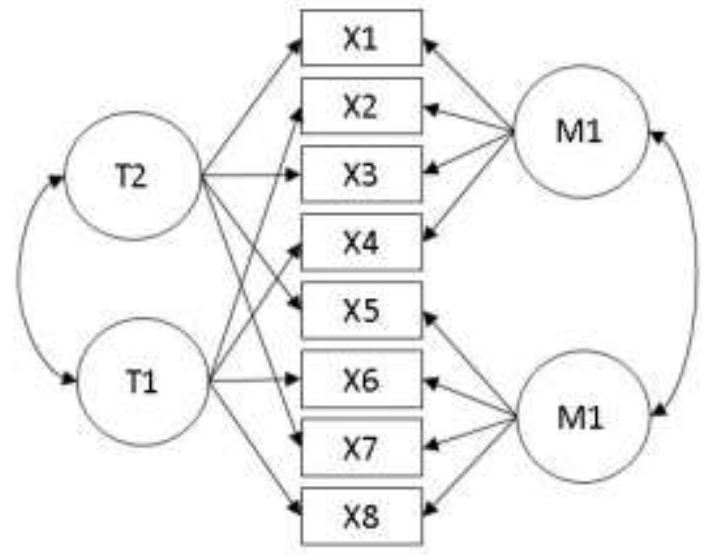

(c) Model Korelasi Trait - Korelasi Metod (KTKM)

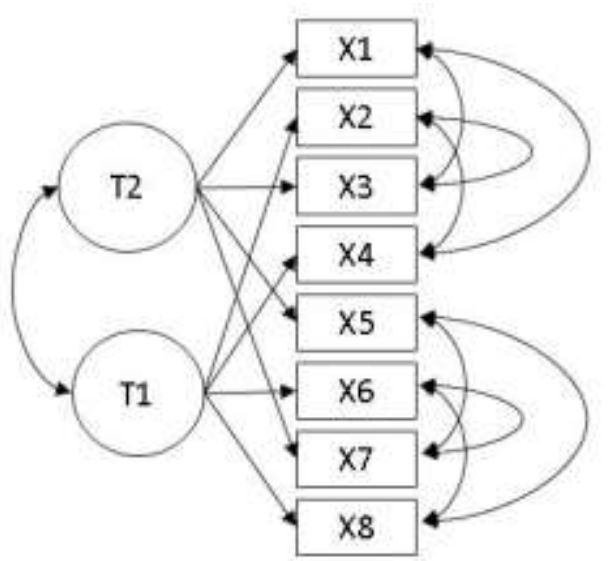

(b) Model Korelasi Trait - Korelasi Unik (KTKU)

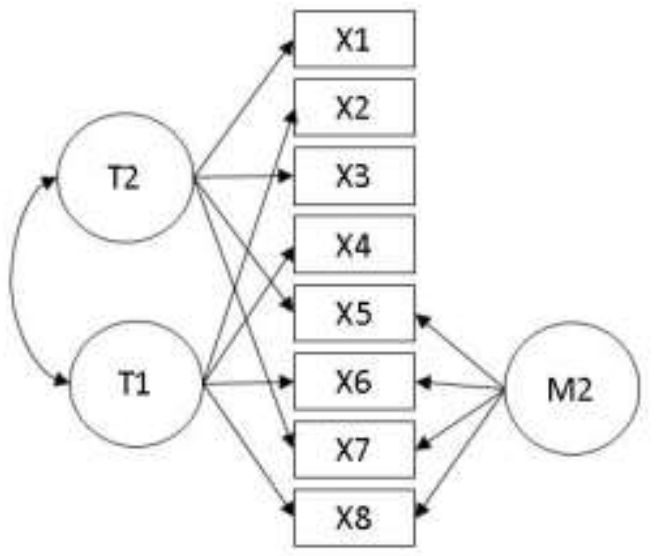

(d) Korelasi Trait-Korelasi Metod Minus 1 (KTKM-1)

Gambar 2. Perbandingan Model-Model yang Mengakomodasi Efek Metode

Model Korelasi Trait Korelasi Unik (KTKU) . Gambar 2(b) melibatkan efek metode akan tetapi tidak dieksplisitkan dalam bentuk konstruk laten. Efek metode dimodelkan dalam bentuk korelasi antar sesatan (error) pengukuran. Korelasi antar eror diberikan pada butir dari metode yang sama. Dalam konsep psikometri eror pengukuran merupakan faktor unik pengukuran, oleh karena itu model ini dinamakan dengan model korelasi trait korelasi faktor unik (correlated trait correlated unique/CTCU). Korelasi antar faktor unik menunjukkan adanya kesamaan antar butir, akan tetapi kesamaan yang dimaksud bukan kesamaan berdasarkan konstruk yang diukur, melainkan berdasarkan kesamaan metode. Dikatakan bukan kesamaan berdasarkan konstruk ukur karena kesamaan dalam hal 
tersebut sudah dijelaskan dalam panah dari butir ke konstruk ukur. Peneliti dapat mengasumsikan bahwa kesamaan yang dimaksud adalah kesamaan metode sehingga korelasi antar eror diberikan pada butir yang memiliki metode sama (Geiser et al., 2012). Untuk model ini, efek metode ditandai dengan besarnya korelasi antar eror tersebut. Semakin besar nilai korelasi, semakin besar efek metode yang dihasilkan oleh pengukuran. Dalam beberapa penelitian (misalnya, Chen, Gobioff, \& Dedrick, 2010), korelasi antar eror hanya diberikan pada salah satu metode saja. Berbeda dengan Gambar 2(b) yang menempatkan korelasi antar eror pada dua metode, korelasi antar dapat pula hanya diberikan pada salah satu metode saja. Tujuannya adalah untuk mempermudah analisis, karena biasanya korelasi antar eror yang diberikan pada banyak butir akan mengganggu proses identifikasi model.

\section{Model Korelasi Trait Korelasi Metode (KTKM). Model yang dipaparkan pada Gambar} 2(c) secara eksplisit memasukkan konstruk ukur dan metode. Model ini dinamakan dengan model korelasi trait korelasi metode karena model ini mengakomodasi korelasi antar konstruk ukur (trait) dan metode. Meski secara konseptual konstruk ukur dan metode dapat memiliki hubungan, namun model ini mengasumsikan bahwa kedua konstruk tersebut tidak berkorelasi (Eid, Lischetzke, Nussbeck, \& Trierweiler, 2003). Dengan demikian, dalam model ini konstruk ukur dan metode dinilai memberikan kontribusi yang terpisah terhadap keberagaman data yang dimodelkan. Keunggulan teknik ini adalah, varians yang terkait dengan indikator, konstruk ukur, konstruk metode, serta komponen residual dapat diketahui. Kendati demikian, model ini memiliki masalah dalam hal identifikasi model (Grayson \& Marsh, 1994), akibatnya program komputer yang dipakai tidak dapat menganalisis atau memberikan hasil yang aneh, misalnya ada nilai varians yang arahnya negatif.

Model Korelasi Trait Korelasi Metode Minus 1 (KTKM-1). Model pada Gambar 2(d) mirip dengan model Gambar 2(c), keduanya mencoba melibatkan konstruk ukur dan metode. Pada model ini konstruk metode yang ada dikurangi satu sehingga yang muncul di dalam model adalah satu konstruk metode. Jika peneliti memiliki tiga metode, maka konstruk model yang dilibatkan di dalam gambar sebanyak dua buah. Oleh karena itu model ini dinamakan dengan Correlated Trait-Correlated Method Minus One (Geiser, Eid, \& Nussbeck, 2008). Seperti halnya dalam variabel dummy, Tujuan dari mengurangi salah satu metode adalah agar model dapat diidentifikasi sehingga analisis dapat dilakukan. 
Ketiga model yang mengakomodasi efek metode secara umum akan memberikan informasi yang setara mengenai efek metode yang dilibatkan dalam pemodelan. Namun masing-masing model memiliki kelebihan dan kelemahan masing-masing. Penggunaan korelasi antar eror akan memiliki kelebihan dalam menghasilkan nilai kecocokan model yang tinggi. Kelemahannya terletak pada tidak dapat diketahuinya efek metode secara langsung, karena konstruk yang menjelaskan metode tidak dieksplisitkan (Pohl \& Steyer, 2010). Model KTKU secara spesifik akan menghasilkan informasi mengenai efek metode, akan tetapi tidak menjelaskan efek yang diakibatkan oleh konstruk ukur. Model KTKM1 dapat mengakomodasi baik efek konstruk dan efek metode akan tetapi hanya satu efek metode saja yang dapat diketahui. Untuk menganalisis model KTKM-1 pada program seperti MPLUS (Muthen \& Muthen, 2005) dan LISREL (Jöreskog \& Sörbom, 1996), kedua konstruk dikorelasikan. Namun nilai korelasi ditetapkan (constrained) sebesar 0. Hal ini dikarenakan dua konstruk yang memiliki posisi yang sama, samasama konstruk eksogen atau endogen, harus dikorelasikan. Untuk program komputer lain misalnya AMOS (Arbukle \& Wothke, 1999), sebelum analisis dijalankan, program akan memberikan peringatan bahwa konstruk ukur dan metode menghendaki untuk dikorelasikan. Untuk melanjutkan analisis peringatan ini bisa kita abaikan dan membiarkan konstruk ukur dan metode tidak memiliki korelasi.

\section{Aplikasi dalam Pemodelan}

Bagian berikut ini akan mendemonstrasikan prosedur analisis model-model yang mengakomodasi efek metode. Analisis akan dilakukan pada data hasil pengukuran harga diri dengan menggunakan Skala Harga Diri Coopersmith yang telah diadaptasi dalam Bahasa Indonesia $(\mathrm{N}=177)$ Perbedaan penggunaan arah butir ditetapkan sebagai metode yang berbeda. Butir-butir positif (favorable) ditetapkan sebagai metode pertama (M1) sedangkan butir-butir negatif (unfavorable) ditetapkan sebagai metode kedua (M2). Data yang dianalisis adalah hasil pemaketan butir (parceling) yang merupakan rerata dari beberapa beberapa butir. Prosedur pembuatan paket butir adalah sebagai berikut.

1. Membelah butir-butir menjadi tiga bagian berdasarkan urutan nomor butir. Belahan pertama (butir 1-8), belahan kedua (butir 916), dan belahan ketiga (butir 17-25). Total butir yang dianalisis adalah 25 .

2. Masing-masing belahan kemudian dibelah lagi berdasarkan arah butir (positif dan negatif). Dari proses pembelahan ini didapatkan enam paket butir, yaitu butir X1, 
X3 dan X5 adalah paket butir positif sedangkan X2, X4 dan X6 adalah paket butir negatif

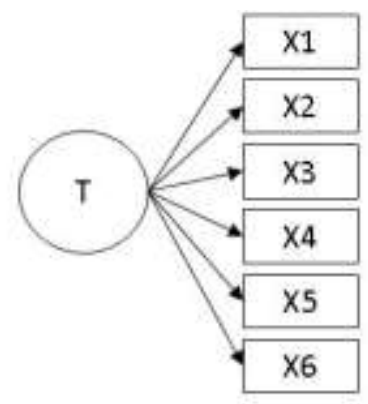

(a) Model Baseline

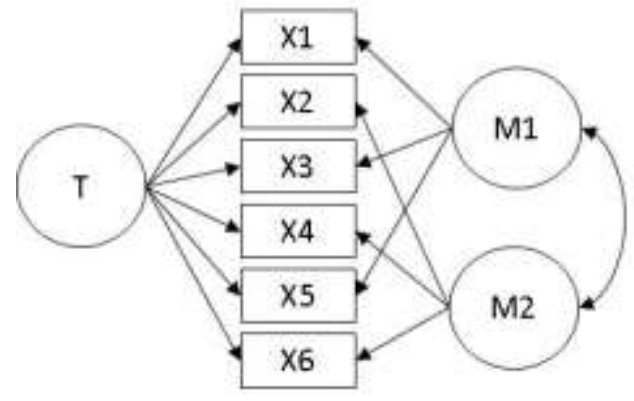

(d) Model KTKM

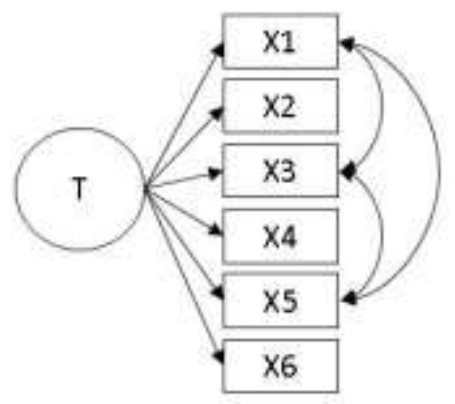

(b) Model KTKE (1)

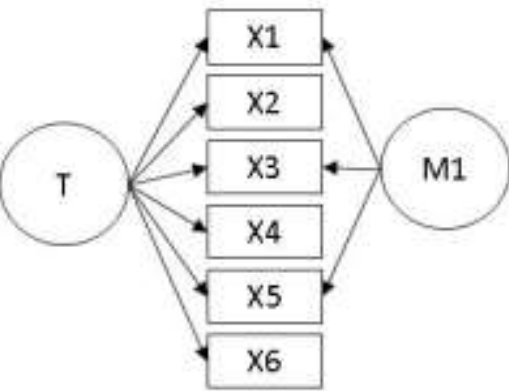

(e) Model KTKM-1 (2)

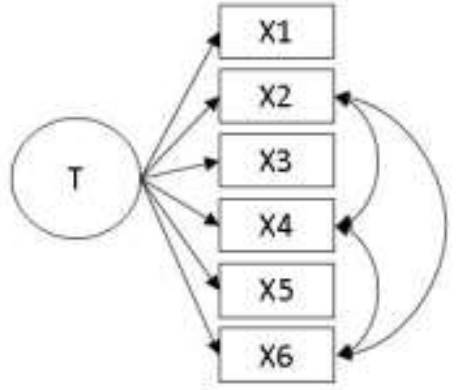

(c) Model KTKE (2)

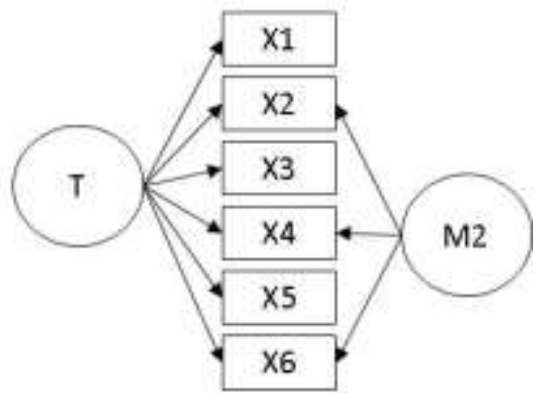

(f) Model KTKM-1 (2)

Gambar 3. Perbandingan Model-Model yang Mengakomodasi Efek Metode

Gambar 3 menjelaskan model-model yang dianalisis. Berbeda dengan yang dicontohkan pada Gambar 2, model ini berisi satu konstruk ukur. Analisis yang dilakukan terhadap model KTKU dan model KTKM-1 dilakukan sebanyak dua kali tergantung pada metode mana yang dimodelkan. Pada model KTKU (1) dan KTKM-1 (1) pemodelan menekankan pada metode 1 (M1), sedangkan pada model KTKU
(2) dan KTKM-1 (2) pemodelan menekankan pada metode 2 (M2).

Tabel 1 menunjukkan matriks korelasi, rerata dan deviasi standar antar paket butir pada kedua variabel. Matriks ini adalah bahan yang dipakai dalam analisis melalui program komputer. Bagi peneliti yang hendak mereplikasi aplikasi ini, dapat menggunakan matriks korelasi tersebut. 
Tabel 1. Matriks Korelasi Data Simulasi $(\mathrm{N}=200)$

\begin{tabular}{lllllll}
\hline & X1 & X2 & X3 & X4 & X5 & X6 \\
\hline X1 & 1 & & & & & \\
X2 & 0,452 & 1 & & & & \\
X3 & 0,425 & 0,460 & 1 & & & \\
X4 & 0,366 & 0,582 & 0,464 & 1 & & \\
X5 & 0,287 & 0,372 & 0,346 & 0,375 & 1 & \\
X6 & 0,123 & 0,360 & 0,212 & 0,257 & 0,236 & 1 \\
\hline Rerata & 0,720 & 0,589 & 0,749 & 0,766 & 0,746 & 0,621 \\
Deviasi & 0,275 & 0,261 & 0,350 & 0,211 & 0,282 & 0,154 \\
\hline
\end{tabular}

Tabel 2. Perbandingan Nilai Kecocokan Model

\begin{tabular}{lllllll}
\hline \multirow{2}{*}{ Indeks } & \multirow{2}{*}{ CFA } & Model & Model & Model & Model & Model \\
& & KTKU (1) & KTKU (2) & KTKM & KTKM-1 (1) & KTKM-1 (2) \\
\hline Kai-Kuadrat & 10,76 & 6,77 & 5,43 & 10,76 & 6,77 & 5,43 \\
P-Value & 0,29 & 0,34 & 0,49 & 0,29 & 0,34 & 0,49 \\
Db & 9 & 6 & 6 & 9 & 6 & 6 \\
CFI & 0,99 & 1,00 & 1,00 & 0,99 & 1,00 & 1,00 \\
TLI & 0,99 & 0,99 & 1,01 & 0,99 & 0,99 & 1,01 \\
RMSEA & 0,03 & 0,03 & 0,00 & 0,03 & 0,03 & 0,00 \\
SRMR & 0,03 & 0,02 & 0,02 & 0,03 & 0,02 & 0,02 \\
AIC & $-162,69$ & $-160,67$ & $-162,02$ & $-162,69$ & $-160,67$ & $-162,02$ \\
BIC & $-105,52$ & $-93,97$ & $-95,32$ & $-105,52$ & $-93,97$ & $-95,32$ \\
\hline
\end{tabular}

Hasil analisis terhadap model-model yang dianalisis dapat dilihat pada Tabel 2. Hasil pengujian model menunjukkan bahwa keenam model yang diuji memenuhi kecocokan model dengan data yang sesuai dengan kriteria yang ditetapkan (Hair, Black, Babin, \& Anderson, 2010). Semua nilai kai-kuadrat menunjukkan nilai yang tidak signifikan ( $p>0.05)$ sehingga menunjukkan bahwa tidak perbedaan yang signifikan antara model dengan data. Hasil ini diperkuat dengan indeks CFI dan TLI yang berada di atas 0.90 dan nilai RMSEA yang berada di atas 0.08. Dari nilai perbandingan ketepatan model secara komparatif melalui indeks AIC dan BIC didapatkan bahwa model yang memiliki nilai AIC dan BIC adalah model KTKU(1) dan KTKM-1(1). Secara deskriptif kedua model tersebut cocok dengan data dibanding dengan model-model lainnya. Namun oleh karena selisih kedua nilai itu sangat kecil maka keempat model yang dianalisis memiliki tingkat kecocokan yang sama. Secara umum temuan ini menunjukkan bahwa penggunaan perbedaan arah kalimat dalam butir, antara arah 
positif dan negatif berkontribusi terhadap

munculnya efek metode dalam pengukuran.

Tabel 3. Bobot Faktor Efek Konstruk dan Metode

\begin{tabular}{|c|c|c|c|c|c|c|}
\hline Butir & Baseline & $\begin{array}{l}\text { KTKE } \\
\text { (1) }\end{array}$ & $\begin{array}{l}\text { KTKE } \\
\text { (2) }\end{array}$ & KTKM & $\begin{array}{l}\text { KTKE-1 } \\
\text { (1) }\end{array}$ & $\begin{array}{l}\text { KTKE-1 } \\
\text { (2) }\end{array}$ \\
\hline \multicolumn{7}{|c|}{ Efek Konstruk (Trait) } \\
\hline $\mathrm{X} 1$ & $0,56 * *$ & $0,53 * *$ & 0,60 ** & 0,56 ** & $0,53 * *$ & $0,60 * *$ \\
\hline $\mathrm{X} 2$ & $0,79 * *$ & $0,81 * *$ & $0,71 * *$ & $0,63 * *$ & $0,81 * *$ & $0,71 * *$ \\
\hline X3 & $0,63 * *$ & $0,59 * *$ & $0,68 * *$ & $0,51 * *$ & $0,59 * *$ & $0,68 * *$ \\
\hline $\mathrm{X} 4$ & $0,72 * *$ & $0,73 * *$ & $0,67 * *$ & $0,79 * *$ & $0,73 * *$ & $0,67 * *$ \\
\hline $\mathrm{X} 5$ & $0,51 * *$ & $0,49 * *$ & $0,52 * *$ & $0,72 * *$ & $0,49 * *$ & $0,52 * *$ \\
\hline $\mathrm{X} 6$ & $0,39 * *$ & $0,40 * *$ & $0,31 * *$ & $0,39 * *$ & $0,40 * *$ & $0,31 * *$ \\
\hline \multicolumn{7}{|c|}{ Efek Metode } \\
\hline & & $0,17 *$ & 0,20 & & $0,25 *$ & $0,54 *$ \\
\hline & & 0,04 & $0,21 *$ & & $0,46 *$ & $0,20 *$ \\
\hline & & 0,08 & 0,07 & & 0,12 & $0,26 *$ \\
\hline
\end{tabular}

Keterangan. ${ }^{*}=\mathrm{p}<0,05 ; * *=\mathrm{p}<0,01$

Setelah indeks kecocokan model didapatkan, langkah selanjutnya adalah mengidentifikasi parameter di dalam model. Dalam proses pemodelan, biasanya identifikasi dilakukan pada model yang paling memiliki tingkat kecocokan paling tinggi. Untuk keperluan pembelajaran, pada dalam tulisan ini parameter di semua model dibandingkan. Dari nilai bobot faktor terlihat bahwa efek konstruk dan metode pada keempat model menjelaskan keragaman data secara signifikan $(p>0,05)$. Dari perbandingan nilai bobot faktor antara sebelum efek metode dilibatkan (model baseline) dan setelah dilibatkan, tidak terjadi perubahan nilai bobot faktor yang substansial. Misalnya paket $\mathrm{X} 1$, pada model baseline didapatkan bobot faktor sebesar 0,56 sedangkan pada model yang mengakomodasi efek metode bobot faktor bergerak antara 0,53 hingga 0,60.

Beberapa poin yang didapatkan dari aplikasi ini adalah sebagai berikut.

1. Perbandingan kecocokan data antara model (Tabel 2). Efek metode muncul ketika model yang mengakomodasi efek model memiliki kecocokan yang lebih tinggi dibanding model modifikasi (dibandingkan dengan indeks komparatif, misalnya AIC). Contoh di tulisan ini menunjukkan bahwa arah butir memberikan efek metode dalam pengukuran.

2. Identifikasi parameter di dalam model (Tabel 3). Dari parameter ini akan didapatkan efek metode yang dihasilkan 
pada tiap butir atau indikator. Pada contoh ini didapatkan bahwa efek metode muncul pada tiap paket butir.

3. Perbandingan parameter antara model yang baseline dan model modifikasi. Perbandingan ini menunjukkan seberapa jauh perubahan efek konstruk ukur dengan munculnya efek konstruk metode. Pada contoh aplikasi didapatkan bahwa munculnya efek konstruk metode tidak mengganggu besarnya efek konstruk ukur.

Dari prosedur di atas langkah selanjutnya dapat berupa memilih model yang memiliki kecocokan tinggi atau memodifikasi alat ukur. Pada contoh di tulisan ini, jika arah butir diasumsikan sebagai dua metode berbeda dalam mengukur, maka peneliti memilih model yang memiliki tingkat kecocokan tinggi. Model yang terbaik kemudian dapat dilibatkan dalam model yang lebih besar (full model) untuk dikorelasikan dengan model yang mengukur konstruk yang lain. Sebaliknya, jika arah butir diasumsikan sebagai dua metode yang sama maka munculnya efek metode yang signifikan menunjukkan adanya masalah dalam butir di dalam alat ukur. Menghadapi situasi demikian, peneliti perlu meninjau kembali butir-butir di dalam alat ukur. Penulisan butir dengan arah yang berbeda ditujukan untuk mengukur konstruk ukur yang sama (Marsh, 1996).
Dengan munculnya efek metode yang signifikan butir yang memiliki arah berbeda berpotensi untuk mengukur konstruk yang berbeda.

\section{SIMPULAN}

Dalam melakukan analisis SEM, ketika peneliti seringkali mendapati model yang diuji memiliki nilai kecocokan model yang rendah. Menghadapi situasi ini, peneliti kemudian melakukan modifikasi model dengan mempertimbangkan indeks modifikasi (modification indices). Indeks modifikasi tersebut menunjukkan bentuk model yang sesuai dengan data yang didapatkan karena bertujuan untuk melibatkan keragaman yang tidak terjangkau oleh model. Namun demikian, kadang apa yang ditunjukkan oleh indeks modifikasi, misalnya mengorelasikan antar eror pengukuran, tidak memiliki dasar teoritik yang kuat. Oleh karena itu peneliti diharapkan memiliki pemahaman yang bagaimana menginterpretasikan indeks modifikasi untuk mengembangkan model yang lebih sesuai dengan data. Tulisan ini menunjukkan bahwa apa yang direkomendasikan oleh indeks modifikasi, menunjukkan munculnya efek metode yang tidak terakomodasi oleh model.

Efek metode merupakan bagian dari eror sistematik yang dapat mengganggu pengambilan kesimpulan dalam penelitian (Campbell \& Fiske, 1959). Sebagai contoh, 
seorang peneliti tertarik untuk meneliti korelasi antara harga diri dan asertifitas. Nilai korelasi yang dihasilkan akan cenderung melambung ketika kedua variabel memiliki sesuatu kebersamaan (common) yang bukan berasal dari konstruk harga diri dan asertifitas. Misalnya kebersamaan berdasarkan kesamaan metode. Melambungnya nilai korelasi diakibatkan oleh karena yang dikorelasikan tidak hanya konstruk ukur melainkan konstruk metode. Oleh karena itu agar mendapatkan nilai korelasi yang benarbenar menjelaskan korelasi antar konstruk ukur, maka efek metode perlu dikendalikan. Tulisan ini mendemonstrasikan beberapa prosedur untuk mengendalikan efek metode dengan cara mengakomodasinya dalam pemodelan.

\section{DAFTAR PUSTAKA}

Abad, F. J., Sorrel, M. A., Garcia, L. F., \& Aluja, A. (2016). Modeling General, Specific, and Method Variance in Personality Measures. Assessment, O(0), $1073191116667547 . \quad$ doi: doi:10.1177/1073191116667547

Andrews, F. M. (1984). Construct Validity and Error Components of Survey Measures: A Structural Modeling Approach. The Public Opinion Quarterly, 48(2), 409442. doi: $10.2307 / 2749034$

Arbukle, J. L., \& Wothke, W. (1999). AMOS 4.0 User's Guide. Chichago: Smallwaters Corp. .

Campbell, D. T., \& Fiske, D. W. (1959). Convergent and discriminant validation by the multitrait-multimethod matrix. Psychological Bulletin, 56(2), 81-105. doi: $10.1037 / \mathrm{h} 0046016$
Castro-Schilo, L., Grimm, K. J., \& Widaman, K. F. (2016). Augmenting the Correlated Trait-Correlated Method Model for Multitrait-Multimethod Data. Structural Equation Modeling: A Multidisciplinary Journal, 23(6), 798-818. doi: 10.1080/10705511.2016.1214919

Chen, Y.-H., Gobioff, G. R., \& Dedrick, R. F. (2010). Factorial invariance of a chinese self-esteem scale for third and sixth grade students: Evaluating method effects associated with positively and negatively worded items The International Journal of Educational and Psychological Assessment, 6(1), 2135.

Cummins, R. A., Woerner, J., Tomyn, A., \& Gibson-Prosser, A. (2012). Quality of Life in Australia. In K. C. Land, A. C. Michalos \& M. J. Sirgy (Eds.), Handbook of Social Indicators and Quality of Life Research. New York: Springer.

Dallal, G. E. (2005). Fixed and Random Factors In G. E. Dallal (Ed.), The Little Handbook of Statistical Practice. Boston, MA.

Eid, M., Lischetzke, T., Nussbeck, F. W., \& Trierweiler, L. I. (2003). Separating trait effects from trait-specific method effects in multitrait-multimethod models: A multiple-indicator CT-C(M-1) model. Psychological Methods, 8(1), 38-60. doi: 10.1037/1082-989x.8.1.38

Fiske, D. W. (1982). Convergent-discriminant validation in measurements and research strategies. In D. Brinbirg \& L. H. Kidder (Eds.), Forms of validity in research. San Francisco: Jossey-Bass.

Geiser, C., Eid, M., \& Nussbeck, F. W. (2008). On the meaning of the latent variables in the CT-C(M-1) model: A comment on Maydeu-Olivares and Coffman (2006). Psychological Methods, 13(1), 49-57. doi: 10.1037/1082-989x.13.1.49 
Geiser, C., Eid, M., West, S. G., Lischetzke, T., \& Nussbeck, F. W. (2012). A Comparison of Method Effects in Two Confirmatory Factor Models for Structurally Different Methods. Structural Equation Modeling: A Multidisciplinary Journal, 19(3), 409436. doi: $10.1080 / 10705511.2012 .687658$

Grayson, D., \& Marsh, H. (1994). Identification with deficient rank loading matrices in confirmatory factor analysis: Multitraitmultimethod models. Psychometrika, 59(1), 121-134. doi: 10.1007/bf02294271

Gu, H., Wen, Z., \& Fan, X. (2015). The impact of wording effect on reliability and validity of the Core Self-Evaluation Scale (CSES): A bi-factor perspective. Personality and Individual Differences, 83, 142-147. doi: http://dx.doi.org/10.1016/j.paid.2015.04 .006

Hair, J. F., Black, W. C., Babin, B. J., \& Anderson, R. E. (2010). Multivariate Data Analysis. New Jersey: Prentice Hall.

Jöreskog, K. G., \& Sörbom, D. (1996). LISREL 8: User's Reference Guide. Chicago Scientific Software International.

Kenny, D. A. (1976). An empirical application of confirmatory factor analysis to the multitrait-multimethod matrix. Journal of Experimental Social Psychology, 12(3), 247-252. doi: 10.1016/00221031(76)90055-X

Kenny, D. A., \& Kashy, D. A. (1992). Analysis of the multitrait-multimethod matrix by confirmatory factor analysis. Psychological Bulletin, 112(1), 165-172. doi: 10.1037/0033-2909.112.1.165

Kline, R. B. (2011). Principles and Practice of Structural Equation Modeling. New York, NY: Guilford Publications, Inc.
Lance, C. E., Baranik, L. E., Lau, A. R., \& A., S. E. (2009). If it ain't trait it must be method: (mis)application of the multitrait-multimethod design in organizational research. In C. E. Lance \& R. L. Vandenberg (Eds.). New York: Routledge

MacKenzie, S. B., \& Podsakoff, P. M. (2012). Common Method Bias in Marketing: Causes, Mechanisms, and Procedural Remedies. Journal of Retailing, 88(4), 542-555. doi: http://dx.doi.org/10.1016/j.jretai.2012.0 8.001

Maitland, A., \& Presser, S. (2016). How Accurately Do Different Evaluation Methods Predict the Reliability of Survey Questions? Journal of Survey Statistics and Methodology, 4(3), 362381. doi: 10.1093/jssam/smw014

Marsh, H. W. (1996). Positive and negative global self-esteem: A substantively meaningful distinction or artifactors? Journal of Personality and Social Psychology, 70(4), 810-819. doi: 10.1037/0022-3514.70.4.810

Marsh, H. W., Asci, F. H., \& Thomas, I. M. (2002). Multitrait-multimethod analyses of two physical self-concept instruments: A cross-cultural perspective. Journal of Sport \& Exercise Psychology, 24(2), 99-119.

McLaughlin, T. P., Khandker, R. K., Kruzikas, D. T., \& Tummala, R. (2006). Overlap of anxiety and depression in a managed care population: prevalence and association with resource utilization. Journal of Clinical Psychiatry, 67(8), 1187-1193.

Morizot, J., Ainsworth, A. T., \& Reise, S. P. (2007). Toward modern psychometrics: Application of item response theory models in personality research. In R. W. Robins, R. C. Fraley \& R. F. Krueger (Eds.), Handbook of Research Methods 
in Personality Psychology. Spring Street, New York, NY: The Guilford Press.

Muthen, L. K., \& Muthen, B. O. (2005). Mplus: Statistical analysis with latent variables: User's guide. Los Angeles, CA.: Muthen $\&$ Muthen.

Podsakoff, P. M., MacKenzie, S. B., \& Podsakoff, N. P. (2011). Sources of Method Bias in Social Science Research and Recommendations on How to Control It. Annual Review of Psychology, 63(1), 539-569. doi: 10.1146/annurev-psych-120710-100452

Pohl, S., \& Steyer, R. (2010). Modeling Common Traits and Method Effects in Multitrait-Multimethod Analysis. Multivariate Behavioral Research, 45(1), 45-72. doi: Doi $10.1080 / 00273170903504729$
Raykov, T., \& Marcoulides, G. A. (2006). A first course in structural equation modeling. Mahwah, NJ: Lawrence Erlbaum Associates.

Urbina, S. (2004). Essentials of psychological testing. Hoboken, NJ.: John Wiley \& Sons, Inc. 